\title{
Delfina Rogowska
}

Instytut Nafty i Gazu - Państwowy Instytut Badawczy

\section{Ocena wpływu czynników występujących na etapie uprawy na emisję GHG w cyklu życia bioetanolu}

\begin{abstract}
W artykule przedstawiono wpływ wybranych składowych emisji GHG w cyklu życia bioetanolu na jej końcową wartość. Obliczenia i symulacje prowadzono w oparciu o wyodrębniony zbiór danych rzeczywistych uzyskanych od producentów rolnych. Stwierdzono, że kluczowymi składowymi emisji GHG w cyklu życia bioetanolu, poza etapem fermentacji alkoholowej, jest zużycie paliwa na etapie uprawy, stosowanie nawozów azotowych oraz emisja polowa podtlenku azotu. W związku z tym dalsza część artykułu koncentruje się głównie wokół zagadnień związanych z wpływem stosowania nawozów azotowych i paliwa do napędzania urządzeń i maszyn rolniczych.
\end{abstract}

Słowa kluczowe: biopaliwa, metodyka LCA, emisja GHG dla etapu uprawy.

\section{The assessment of the impact of factors occurring on the cultivation stage on GHG emission in the ethanol life cycle}

In the article, the impact of selected components of GHG emission in the life cycle of bioethanol on its final value was considered. Calculations and simulations were carried out based on an extracted set of actual values received from farmers. It was found that key elements in the life cycle of bioethanol, besides the fermentation step, are the use of fuel at the cultivation stage, use of nitrogen fertilizers and field emission of nitrous oxide. Therefore, further parts of the article focuses mainly on issues related to the impact of the use of nitrogen fertilizers and fuel to power equipment and agricultural machinery.

Key words: biofuel, LCA methodology, GHG emission for cultivation stage.

\section{Wstęp}

Dyrektywa 2009/28/WE [14] zwana dyrektywą RED jest istotnym dokumentem regulującym promocję energii ze źródeł odnawialnych. Nakłada ona cel osiągnięcia 20\% energii ze źródeł odnawialnych w roku 2020 brutto, w tym 10\% w transporcie, jednocześnie wymagając, aby do tego celu były uwzględniane wyłącznie biopaliwa spełniające kryteria zrównoważonego rozwoju. Kryteria te zostały zdefiniowane w artykule 17 dyrektywy RED [14]. Można je podzielić na dwie grupy zagadnień: pierwsza dotyczy redukcji emisji gazów cieplarnianych (GHG), druga - wymagań wobec gruntów, na których uprawiane były surowce rolnicze. W niniejszym artykule kwestie dotyczące kryteriów dla gruntów nie będą omawiane.

Wytyczne w zakresie obliczania emisji gazów cieplarnianych zdefiniowane zostały w artykule 19 dyrektywy RED [14]:
„Do celów art. 17 ust. 2 ograniczenie emisji gazów cieplarnianych dzięki wykorzystaniu biopaliw i biopłynów oblicza się w następujący sposób:

a) jeżeli wartość standardowa ograniczenia emisji gazów cieplarnianych dla danej ścieżki produkcji została określona w załączniku V część A lub B i jeżeli wartość $e_{l}$ dla tych biopaliw lub biopłynów obliczona zgodnie z załącznikiem $\mathrm{V}$ część $\mathrm{C}$ pkt. 7 jest równa zero lub jest mniejsza od zera, poprzez zastosowanie tej wartości standardowej;

b) poprzez zastosowanie wartości rzeczywistej obliczanej zgodnie z metodologią określoną w załączniku V część C; lub

c) poprzez zastosowanie wartości będącej sumą czynników wzoru, o którym mowa w załączniku V część C pkt. 1, gdzie szczegółowe wartości standardowe określone w załączniku V część D lub E mogą być użyte dla niektórych 
czynników, a wartości rzeczywiste, obliczone zgodnie z metodami określonymi w załączniku $\mathrm{V}$ część $\mathrm{C}$, dla wszystkich innych czynników".

Załącznik V, część C precyzuje metodykę obliczania emisji GHG, której podstawą jest wzór:

$$
E=e_{e c}+e_{l}+e_{p}+e_{t d}+e_{u}-e_{s c a}-e_{c c s}-e_{c c r}-e_{e e}
$$

gdzie:

$E$ - emisja całkowita spowodowana stosowaniem paliwa,

$e_{e c}$ - emisja wywołana wydobyciem lub uprawą surowców,

$e_{l}-$ emisja w ujęciu rocznym wynikająca ze zmian ilości pierwiastka węgla w związku z przekształceniem sposobu użytkowania gruntu,

$e_{p}$ - emisja spowodowana procesami technologicznymi,

$e_{t d}$ - emisja wywołana transportem i dystrybucją,

$e_{u}$ - emisja spowodowana stosowanym paliwem,

$e_{s c a}-$ wartość ograniczenia emisji wynikającego z akumulacji pierwiastka węgla w glebie dzięki lepszej gospodarce rolnej,

$e_{c c s}-$ ograniczenie emisji wywołane wychwytywaniem ditlenku węgla i składowaniem go w głębokich strukturach geologicznych,

$e_{c c r}-$ ograniczanie emisji spowodowane wychwytywaniem ditlenku węgla i jego zastępowaniem,

$e_{e e}$ - ograniczenie emisji dzięki zwiększonej produkcji energii elektrycznej w wyniku kogeneracji.

Zgodnie z pkt. c artykułu 19 dyrektywy [14] możliwe jest stosowanie kombinacji wartości rzeczywistych i cząstkowych wartości standardowych. Etap uprawy surowców jest charakterystyczny: poza wartościami rzeczywistymi, standardowymi, możliwe jest tu wykorzystywanie również średnich emisji GHG dla określonych obszarów geograficznych, jeśli wartości te zostały zatwierdzone przez Komisję Europejską.

Należy tu zaznaczyć, że przedstawione powyżej podejście stanowi pewnego rodzaju kompromis zawarty w europejskim akcie prawnym. Naukowe podejście do zagadnień związanych z oceną wpływu biopaliw na środowisko ma dużo bardziej złożony charakter, co zostało szczegółowo omówione na przykładzie Szwecji [5].

\section{Składowe emisji GHG w cyklu życia bioetanolu}

Każdy z elementów wzoru (1) reprezentuje oddzielny etap w cyklu życia biopaliwa, tj. pozyskanie surowców (uprawa), przetwarzanie biomasy - produkcja biokomponentu, transport i dystrybucja gotowych produktów oraz spalanie. Ze względu na fakt przyjmowania, że emisja GHG ze spalania dla biopaliw wynosi zero, etap spalania nie będzie analizowany $w$ ramach niniejszego artykułu.

Dla wybranych ścieżek produkcji biopaliw dyrektywa 2009/28/WE przedstawiła standardowe wartości emisji GHG, wraz z podaniem wartości cząstkowych. Rozkład emisji GHG w cyklu życia bioetanolu, dla wybranych ścieżek, przedstawiono na rysunku 1.

Uprawa i proces technologiczny to dwie główne składowe emisji GHG w cyklu życia bioetanolu. Na rysunku 1 przedstawione zostały wartości standardowe, które są zawyżone względem wartości typowych po to, aby uniknąć sytuacji, gdy podmiot deklaruje niższą wartość emisji GHG niż rzeczywista. Stąd przy rosnących celach redukcji GHG pojawia się konieczność prowadzenia obliczeń autentycznych wartości emisji GHG w cyklu życia biopaliw; w wielu przypadkach będą one dużo korzystniejsze niż wartość standardowa. Wartości liczbowe przedstawione w dyrektywie [14] i zobrazowane na rysunku 1 stanowią dane uśrednione, natomiast dane rzeczywiste, uzyskane w wyniku indywidualnych kalkulacji czy wyprowadzone dla różnych ścieżek, będą się znacząco między sobą różniły [13]. W Polsce dominu- jącym surowcem do produkcji etanolu jest kukurydza [11]. Dlatego też w dalszej części artykułu przedstawiono jedynie aspekty związane z oceną emisji GHG w cyklu życia bioetanolu produkowanego właśnie z tego surowca.

Jak wspomniano powyżej, na emisję GHG w cyklu życia biopaliw składają się dwa główne elementy: uprawa

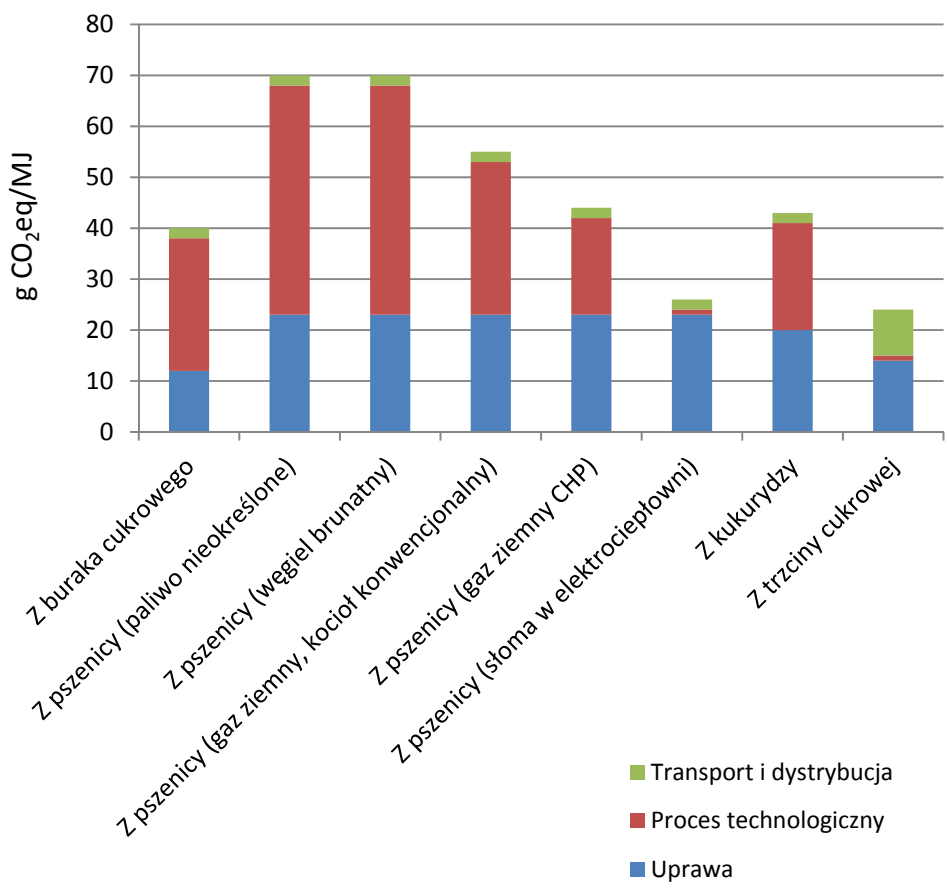

Rys. 1. Rozkład emisji GHG w cyklu życia bioetanolu dla wybranych ścieżek produkcji 
oraz proces technologiczny. Charakter działalności prowadzony w ramach tych odrębnych procesów jest bardzo różny, występują również odmienne czynniki generujące emisję GHG, stąd metodologia obliczeń na każdym etapie będzie inna.

Kwestie wpływu np. sposobu alokacji oraz pozostałych czynników oddziałujących na wynik emisji GHG na etapie produkcji biokomponentu były już przedmiotem analiz $[1,2$, $3,7,8,10]$. W związku z tym w ramach niniejszego artykułu nacisk zostanie położony głównie na czynniki wpływające na wynik emisji GHG, występujące na pozostałych etapach w cyklu życia etanolu.
Opierając się na danych zawartych w kalkulatorze Biograce [12], dla ścieżki produkcji etanolu z kukurydzy, należy stwierdzić, że na emisję na etapie uprawy składają się:

- emisja ze spalania oleju napędowego w maszynach rolniczych $-27,51 \%$ emisji GHG z etapu uprawy,

- emisja ze stosowania nawozów i środków ochrony roślin - 51,21\% emisji GHG z etapu uprawy,

- emisja polowa $\mathrm{N}_{2} \mathrm{O}-21,28 \%$.

Dla tej ścieżki produkcji elementami najbardziej znaczącymi są emisja ze spalania paliwa w maszynach rolniczych oraz emisja wynikająca ze stosowania nawozów i środków ochrony roślin.

\section{Ustalenie zbioru danych wejściowych, w tym ścieżki produkcji bioetanolu w odniesieniu do warunków polskich}

Jak wykazała analiza przeprowadzona przez autorkę [6], krytyczne ze względu na otrzymany wynik jest przyjęcie wskaźników emisji dla poszczególnych strumieni wejściowych. Dla dokonania oceny wpływu poszczególnych składowych, bazując na danych zawartych w opracowaniu [9], wyodrębniono zbiór danych wejściowych do obliczeń emisji GHG w cyklu życia etanolu z kukurydzy. Charakteryzuje się on następującymi cechami:

- są to dane rzeczywiste uzyskane od producentów rolnych,

- dane pochodzą od różnych producentów rolnych - aby otrzymać zbiór reprezentatywny,

- dane wywodzą się z lat 2013-2015,

- dane uzyskano od rolników uprawiających na terenie województwa kujawsko-pomorskiego. Skupienie się na jednym województwie przyczyni się do zachowania spójności i jednolitości danych, a tym samym zmniejszy ryzyko wpływu zbyt wielu czynników (takich jak np. ukształtowanie terenu).

Dane te przedstawiono w tablicach 1-3.

W tablicy 2, w wierszach od 1 do 27, podano zużycie nawozów w poszczególnych gospodarstwach rolnych w kg/ha/rok, natomiast w wierszach nagłówkowych (2-5) scharakteryzowano poszczególne nawozy ze względu na zawartość kluczowych składników (azotu, fosforu, potasu i wapnia).

Emisja GHG wynikająca ze zużycia nawozów podawana jest jako wartość w odniesieniu do zużytego azotu, fosforu i potasu. Stąd przed przeprowadzeniem obliczeń należało przeliczyć poszczególne ilości zużytych pierwiastków. Wyniki tych działań przedstawiono w tabeli 3.

Do obliczeń wykorzystano dane uśrednione. Dla zapewnienia spójności wykorzystanej metodologii z tą podaną w dyrektywie RED [14] do obliczeń zastosowano kalkulator Biograce [12]. Wprowadzono jedynie własne dane wejściowe. Symulacje zostały przeprowadzone w III wariantach.
Tablica 1. Dane wejściowe do obliczeń emisji GHG dla uprawy kukurydzy do produkcji bioetanolu

\begin{tabular}{|r|r|c|c|c|}
\hline $\mathrm{Nr}$ & $\begin{array}{c}\text { Plon } \\
{[\mathrm{t} / \mathrm{ha}]}\end{array}$ & $\begin{array}{c}\text { Wilgotność ziarna } \\
{[\%]}\end{array}$ & $\begin{array}{c}\text { Diesel } \\
{[1 / \mathrm{ha}]}\end{array}$ & $\begin{array}{c}\text { Pestycydy } \\
{[\mathrm{kg} / \mathrm{ha}]}\end{array}$ \\
\hline 1. & 12,00 & 30,00 & 90,00 & 1,64 \\
\hline 2. & 7,20 & 31,00 & 90,00 & 1,64 \\
\hline 3. & 8,60 & 29,00 & 90,00 & 1,64 \\
\hline 4. & 14,20 & 33,00 & 90,00 & 5,00 \\
\hline 5. & 11,50 & 31,00 & 90,00 & 5,00 \\
\hline 6. & 9,00 & 34,00 & 90,00 & 5,00 \\
\hline 7. & 12,50 & 30,00 & 60,00 & 1,74 \\
\hline 8. & 11,80 & 30,00 & 60,00 & 2,14 \\
\hline 9. & 8,50 & 30,00 & 60,00 & 2,14 \\
\hline 10. & 11,50 & 33,00 & 85,00 & 1,64 \\
\hline 11. & 7,10 & 32,00 & 85,00 & 1,64 \\
\hline 12. & 9,00 & 28,00 & 85,00 & 1,64 \\
\hline 13. & 14,00 & 30,00 & 80,00 & 3,20 \\
\hline 14. & 9,00 & 28,00 & 80,00 & 3,20 \\
\hline 15. & 9,00 & 28,00 & 80,00 & 3,20 \\
\hline 16. & 19,00 & 34,00 & 90,00 & 5,00 \\
\hline 17. & 11,80 & 30,00 & 90,00 & 5,00 \\
\hline 18. & 9,20 & 34,00 & 90,00 & 5,00 \\
\hline 19. & 11,50 & 31,00 & 88,00 & 1,64 \\
\hline 20. & 7,70 & 32,00 & 88,00 & 1,64 \\
\hline 21. & 8,50 & 28,00 & 88,00 & 1,64 \\
\hline 22. & 10,00 & 32,00 & 85,00 & 7,00 \\
\hline 23. & 12,00 & 33,00 & 85,00 & 7,00 \\
\hline 24. & 8,00 & 30,00 & 85,00 & 7,00 \\
\hline 25. & 12,00 & 30,00 & 90,00 & 1,64 \\
\hline 26. & 6,00 & 32,00 & 90,00 & 1,64 \\
\hline 27. & 8,00 & 28,00 & 90,00 & 1,64 \\
\hline Srednia & 10,32 & 31,00 & 84,22 & 3,20 \\
\hline & & & & \\
\hline
\end{tabular}


Tablica 2. Dane rolnicze do obliczeń emisji GHG dla etanolu z kukurydzy - stosowane nawozy [kg/ha/rok]

\begin{tabular}{|c|c|c|c|c|c|c|c|c|c|c|c|}
\hline & $\begin{array}{c}\text { Fosforan } \\
\text { amonu }\end{array}$ & $\begin{array}{l}\text { Korn } \\
\text { Kali } \\
40 \%\end{array}$ & $\begin{array}{c}\text { Micro- } \\
\text { helat }\end{array}$ & $\begin{array}{c}\text { Mikrovit } \\
\mathrm{Zn}\end{array}$ & $\begin{array}{l}\text { Mikrovit } \\
\text { Bor }\end{array}$ & Mocznik & $\begin{array}{l}\text { Siarczan } \\
\text { magnezu }\end{array}$ & $\begin{array}{c}\text { Sól } \\
\text { potasowa }\end{array}$ & $\begin{array}{l}\text { Super- } \\
\text { fosfat }\end{array}$ & Suprofos & $\begin{array}{c}\text { Wapno } \\
40 \% \mathrm{CAO}\end{array}$ \\
\hline $\begin{array}{c}\text { Zawartość N, } \\
\text { ułamek } \\
\text { masowy }\end{array}$ & 0,18 & 0 & - & - & - & 0,46 & - & - & - & 0,050 & - \\
\hline $\begin{array}{c}\text { Zawartość } \\
\mathrm{P}_{2} \mathrm{O}_{5} \text {, ułamek } \\
\text { masowy }\end{array}$ & 0,46 & & - & - & - & - & - & - & 0,4 & 0,100 & - \\
\hline $\begin{array}{c}\text { Zawartość } \\
\mathrm{K}_{2} \mathrm{O} \text {, ułamek } \\
\text { masowy }\end{array}$ & 0,05 & 0,4 & - & - & - & - & - & - & - & 0,250 & - \\
\hline $\begin{array}{c}\text { Zawartość } \\
\mathrm{CaO} \text {, ułamek } \\
\text { masowy }\end{array}$ & - & - & - & - & - & - & - & - & 0,1 & 0,025 & 0,4 \\
\hline 1. & & & & & & 350 & & & & 500 & \\
\hline 2. & & & & & & 350 & & & & 500 & \\
\hline 3. & & & & & & 350 & & & & 500 & \\
\hline 4. & 200 & & 2 & & & 350 & 30 & 160 & & & 3000 \\
\hline 5. & 200 & & 2 & & & 350 & 30 & 160 & & & 3000 \\
\hline 6. & 200 & & 2 & & & 350 & 30 & 160 & & & 3000 \\
\hline 7. & 200 & 500 & & & & 450 & & & & & \\
\hline 8. & 200 & 450 & & & & 450 & & & & & \\
\hline 9. & 200 & 450 & & & & 450 & & & & & \\
\hline 10. & & & & & & 350 & & & & 500 & \\
\hline 11. & & & & & & 350 & & & & 500 & \\
\hline 12. & & & & & & 350 & & & & 500 & \\
\hline 13. & 200 & & & & & 200 & 300 & 200 & & & \\
\hline 14. & 200 & & & & & 200 & 300 & 200 & & & \\
\hline 15. & 200 & & & & & 200 & 300 & 200 & & & \\
\hline 16. & 200 & & 2 & & & 350 & 30 & 160 & & & 3000 \\
\hline 17. & 200 & & 2 & & & 350 & 30 & 160 & & & 3000 \\
\hline 18. & 200 & & 2 & & & 350 & 30 & 160 & & & 3000 \\
\hline 19. & & & & & & 350 & & & & 500 & \\
\hline 20. & & & & & & 350 & & & & 500 & \\
\hline 21. & & & & & & 350 & & & & 500 & \\
\hline 22. & & & & 5 litrów & 4 litry & 300 & & 200 & 200 & & \\
\hline 23. & & & & 5 litrów & 4 litry & 300 & & 200 & 200 & & \\
\hline 24. & & & & 5 litrów & 4 litry & 300 & & 200 & 200 & & \\
\hline 25. & & & & & & 350 & & & & 500 & \\
\hline 26. & & & & & & 350 & & & & 500 & \\
\hline 27. & & & & & & 350 & & & & 500 & \\
\hline
\end{tabular}

\section{Wariant I. Emisja wyliczona z wykorzystaniem kalkulatora Biograce}

Do arkusza kalkulacyjnego dostarczonego przez Biograce [12], bez dokonania modyfikacji w metodologii obliczeń wprowadzono źródłowe (uśrednione) dane zawarte w tabli- cach 1-3. Wyniki obliczeń zamieszczono w tablicy 4 - gdzie zachowano układ oryginalny z Biograce.

Uzyskany wynik to $37,7 \mathrm{~g} \mathrm{CO}_{2}$ eq/MJ, co daje 55-procentową redukcję emisji gazów cieplarnianych, liczoną względem odpowiednika kopalnego. 
Tablica 3. Ilość azotu, fosforu, potasu i wapnia zużyta do uprawy kukurydzy na potrzeby produkcji bioetanolu

\begin{tabular}{|c|c|c|c|c|}
\hline $\mathrm{Nr}$ & $\begin{array}{c}\mathrm{N} \text { nieorg. } \\
{[\mathrm{kg} \mathrm{N} / \mathrm{ha}]}\end{array}$ & $\begin{array}{c}\mathrm{P} \\
{\left[\mathrm{kg} \mathrm{P}_{2} \mathrm{O}_{5} / \mathrm{ha}\right]}\end{array}$ & $\begin{array}{c}\mathrm{K} \\
{\left[\mathrm{kg} \mathrm{K}_{2} \mathrm{O} / \mathrm{ha}\right]}\end{array}$ & $\begin{array}{c}\mathrm{Ca} \\
{[\mathrm{kg} \mathrm{CaO} / \mathrm{ha}]}\end{array}$ \\
\hline 1. & 186,00 & 50,00 & 125,00 & 12,50 \\
\hline 2. & 186,00 & 50,00 & 125,00 & 12,50 \\
\hline 3. & 186,00 & 50,00 & 125,00 & 12,50 \\
\hline 4. & 197,00 & 92,00 & 106,00 & 0,00 \\
\hline 5. & 197,00 & 92,00 & 106,00 & 0,00 \\
\hline 6. & 197,00 & 92,00 & 106,00 & 0,00 \\
\hline 7. & 243,00 & 92,00 & 210,00 & 0,00 \\
\hline 8. & 243,00 & 92,00 & 190,00 & 0,00 \\
\hline 9. & 243,00 & 92,00 & 190,00 & 0,00 \\
\hline 10. & 186,00 & 50,00 & 125,00 & 12,50 \\
\hline 11. & 186,00 & 50,00 & 125,00 & 12,50 \\
\hline 12. & 186,00 & 50,00 & 125,00 & 12,50 \\
\hline 13. & 128,00 & 92,00 & 130,00 & 0,00 \\
\hline 14. & 128,00 & 92,00 & 130,00 & 0,00 \\
\hline
\end{tabular}

\begin{tabular}{|c|c|c|c|c|}
\hline $\mathrm{Nr}$ & $\begin{array}{c}\mathrm{N} \text { nieorg. } \\
{[\mathrm{kg} \mathrm{N} / \mathrm{ha}]}\end{array}$ & $\begin{array}{c}\mathrm{P} \\
{\left[\mathrm{kg}_{2} \mathrm{O}_{5} / \mathrm{ha}\right]}\end{array}$ & $\left.\begin{array}{c}\mathrm{K} \\
{[\mathrm{kg} \mathrm{K}}\end{array} \mathrm{O}^{\mathrm{h}} \mathrm{h}\right]$ & $\begin{array}{c}\mathrm{Ca} \\
{[\mathrm{kg} \mathrm{CaO} / \mathrm{ha}]}\end{array}$ \\
\hline 15. & 128,00 & 92,00 & 130,00 & 0,00 \\
\hline 16. & 197,00 & 92,00 & 106,00 & 0,00 \\
\hline 17. & 197,00 & 92,00 & 106,00 & 0,00 \\
\hline 18. & 197,00 & 92,00 & 106,00 & 0,00 \\
\hline 19. & 186,00 & 50,00 & 125,00 & 12,50 \\
\hline 20. & 186,00 & 50,00 & 125,00 & 12,50 \\
\hline 21. & 186,00 & 50,00 & 125,00 & 12,50 \\
\hline 22. & 138,00 & 80,00 & 120,00 & 20,00 \\
\hline 23. & 138,00 & 80,00 & 120,00 & 20,00 \\
\hline 24. & 138,00 & 80,00 & 120,00 & 20,00 \\
\hline 25. & 186,00 & 50,00 & 125,00 & 12,50 \\
\hline 26. & 186,00 & 50,00 & 125,00 & 12,50 \\
\hline 27. & 186,00 & 50,00 & 125,00 & 12,50 \\
\hline Średnia & 183,00 & 72,00 & 128,74 & 7,78 \\
\hline
\end{tabular}

Tablica 4. Wyniki obliczeń. Wariant I

\begin{tabular}{|c|c|c|c|c|c|c|}
\hline All results in & Non-allocated & Allocation & Allocated & Total & Actual/ & Default values \\
\hline $\mathrm{g} \mathrm{CO}_{2, \mathrm{eq}} / \mathrm{MJ}_{\text {Ethanol }}$ & results & factor & results & & Default & RED Annex V.D \\
\hline Cultivation $e_{e c}$ & & & & 14,4 & A & 20,00 \\
\hline Cultivation of corn & 26,33 & $54,6 \%$ & 14,38 & & & 20,18 \\
\hline Processing $e_{p}$ & & & & 21,5 & A & 21,00 \\
\hline Ethanol plant & 39,28 & $54,6 \%$ & 21,45 & & & 20,96 \\
\hline Transport $e_{t d}$ & & & & 1,9 & $\mathbf{A}$ & 2,00 \\
\hline Transport of corn & 0,62 & $54,6 \%$ & 0,34 & & & 0,28 \\
\hline Transport of ethanol to depot & 0,60 & $100,0 \%$ & 0,60 & & & 1,10 \\
\hline Transport to filling station & 0,93 & $100,0 \%$ & 0,93 & & & 0,44 \\
\hline Land use change $e_{l}$ & 0,00 & $54,6 \%$ & 0,00 & 0,0 & & 0,00 \\
\hline Bonus or $e_{s c a}$ & 0,00 & $100,0 \%$ & 0,00 & 0,0 & & 0,00 \\
\hline$e_{c c r}+e_{c c s}$ & 0,00 & $100,0 \%$ & 0,00 & 0,0 & & 0,00 \\
\hline Totals & 67,8 & & & 37,7 & & 43,00 \\
\hline
\end{tabular}

\section{Wariant II. Emisja wyliczona z wykorzystaniem kalkulatora Biograce i polskiego wskaźnika emisji GHG dla nawozów azotowych}

Podany w kalkulatorze Biograce wskaźnik emisji GHG dla nawozów azotowych jest wskaźnikiem średnim dla UE i wynosi 5880,6 $\mathrm{g} \mathrm{CO}_{2 \mathrm{eq}} / \mathrm{kg} \mathrm{N}$. Do wyliczeń emisji GHG dla Polski podano wskaźnik pozyskany od polskich producentów nawozów azotowych, wynoszący 3414,2 $\mathrm{g} \mathrm{CO}_{2 \mathrm{eq}} / \mathrm{kg} \mathrm{N}$ [4]. Wartość ta została wykorzystana do obliczeń w miejsce domyślnego wskaźnika emisji GHG. Wyniki obliczeń przedstawiono w tablicy 5.
Uzyskano wynik 34,0 $\mathrm{g} \mathrm{CO}_{2}$ eq/MJ, co daje 59-procentową redukcję emisji GHG etanolu uzyskanego z kukurydzy.

Przyjęte do obliczeń wskaźniki emisji GHG dla nawozów azotowych są wartościami uśrednionymi (zarówno w przypadku wariantu I, jak i II). Należy zwrócić uwagę na fakt, że niektóre systemy dobrowolnie podają wskaźniki emisji GHG dla konkretnych nawozów sztucznych. Dane źródłowe przyjęte do przedstawianych obliczeń zawierają duży zbiór rekordów, gdzie jednym z głównych nawozów był mocznik. Dla mocznika wskaźnik emisji GHG wynosi $3310 \mathrm{~g} \mathrm{CO}_{2 \mathrm{eq}} / \mathrm{kg} \mathrm{N}$. 
Tablica 5. Wyniki obliczeń. Wariant II

\begin{tabular}{|c|c|c|c|c|c|c|}
\hline All results in & Non-allocated & Allocation & Allocated & Total & Actual/ & Default values \\
\hline $\mathrm{g} \mathrm{CO}_{2, \mathrm{eq}} / \mathrm{MJ}_{\text {Ethanol }}$ & results & factor & results & & Default & RED Annex V.D \\
\hline Cultivation $e_{e c}$ & & & & 10,7 & A & 20,00 \\
\hline Cultivation of corn & 19,61 & $54,6 \%$ & 10,71 & & & 20,18 \\
\hline Processing $e_{p}$ & & & & 21,5 & A & 21,00 \\
\hline Ethanol plant & 39,28 & $54,6 \%$ & 21,45 & & & 20,96 \\
\hline Transport $e_{t d}$ & & & & 1,9 & $\mathbf{A}$ & 2,00 \\
\hline Transport of corn & 0,62 & $54,6 \%$ & 0,34 & & & 0,28 \\
\hline Transport of ethanol to depot & 0,60 & $100,0 \%$ & 0,60 & & & 1,10 \\
\hline Transport to filling station & 0,93 & $100,0 \%$ & 0,93 & & & 0,44 \\
\hline Land use change $e_{l}$ & 0,00 & $54,6 \%$ & 0,00 & 0,0 & & 0,00 \\
\hline Bonus or $e_{s c a}$ & 0,00 & $100,0 \%$ & 0,00 & 0,0 & & 0,00 \\
\hline$e_{c c r}+e_{c c s}$ & 0,00 & $100,0 \%$ & 0,00 & 0,0 & & 0,00 \\
\hline Totals & 61,1 & & & 34,0 & & 43,00 \\
\hline
\end{tabular}

Wariant III. Emisja wyliczona z wykorzystaniem kalkulatora Biograce i wskaźnika emisji GHG dla mocznika

W tym wariancie obliczeń dla uproszczenia przyjęto, że wszystkie nawozy azotowe charakteryzują się takim wskaź- nikiem emisji GHG jak mocznik. Wyniki obliczeń przedstawiono w tablicy 6.

W efekcie obliczeń uzyskano wynik $33,9 \mathrm{~g} \mathrm{CO}_{2}$ eq/MJ, co pozwala na osiągnięcie 60-procentowej redukcji emisji GHG dla etanolu produkowanego z kukurydzy.

Tablica 6. Wyniki obliczeń. Wariant III

\begin{tabular}{|c|c|c|c|c|c|c|}
\hline All results in & Non-allocated & Allocation & Allocated & Total & Actual/ & Default values \\
\hline $\mathrm{g} \mathrm{CO}_{2, \mathrm{eq}} / \mathrm{MJ}_{\text {Ethanol }}$ & results & factor & results & & Default & RED Annex V.D \\
\hline Cultivation $e_{e c}$ & & & & 10,6 & A & 20,00 \\
\hline Cultivation of corn & 19,33 & $54,6 \%$ & 10,56 & & & 20,18 \\
\hline Processing $e_{p}$ & & & & 21,5 & $\mathbf{A}$ & 21,00 \\
\hline Ethanol plant & 39,28 & $54,6 \%$ & 21,45 & & & 20,96 \\
\hline Transport $e_{t d}$ & & & & 1,9 & $\mathbf{A}$ & 2,00 \\
\hline Transport of corn & 0,62 & $54,6 \%$ & 0,34 & & & 0,28 \\
\hline Transport of ethanol to depot & 0,60 & $100,0 \%$ & 0,60 & & & 1,10 \\
\hline Transport to filling station & 0,93 & $100,0 \%$ & 0,93 & & & 0,44 \\
\hline Land use change $e_{l}$ & 0,00 & $54,6 \%$ & 0,00 & 0,0 & & 0,00 \\
\hline Bonus or $e_{s c a}$ & 0,00 & $100,0 \%$ & 0,00 & 0,0 & & 0,00 \\
\hline$e_{c c r}+e_{c c s}$ & 0,00 & $100,0 \%$ & 0,00 & 0,0 & & 0,00 \\
\hline Totals & 60,8 & & & 33,9 & & 43,00 \\
\hline
\end{tabular}

\section{Podsumowanie}

Kluczowymi elementami emisji GHG w cyklu życia bioetanolu, poza etapem fermentacji, są: emisja wnoszona z paliwem wykorzystywanym do prac rolniczych, emisja związana z nawozami azotowymi oraz polowa emisja $\mathrm{N}_{2} \mathrm{O}$.
Zmniejszenie wskaźnika emisji GHG dla nawozów azotowych o $54,26 \%$ będzie skutkowało obniżeniem emisji GHG w cyklu życia bioetanolu o 12,47\%. Obliczenia przedstawione w niniejszym artykule wskazują, że istotny dla końcowej 
emisji GHG w cyklu życia etanolu jest również rodzaj nawozów (producent, wskaźnik emisji GHG) stosowanych na etapie uprawy np. kukurydzy. Powinno to skutkować wyższą świadomością rolników w tym zakresie, a także zwiększeniem uwagi producentów nawozów również na aspekt redukcji emisji gazów cieplarnianych. Wobec przedstawionych w artykule obliczeń znaczenia nabierają innowacyjne rozwiązania technologiczne wdrażane przez producentów nawozów, np. w Grupie Azoty S.A.

W związku z tym, że drugą co do wielkości składową emisji GHG dla etanolu produkowanego z kukurydzy jest emisja ze spalania oleju napędowego w maszynach rolniczych, należy również podjąć prace nad optymalizacją tego czynnika.

Prosimy cytować jako: Nafta-Gaz 2017, nr 2, s. 119-125, DOI: 10.18668/NG.2017.02.07

Artykuł nadesłano do Redakcji 30.11.2016 r. Zatwierdzono do druku 20.01.2017 r.

Artykuł powstał na podstawie pracy statutowej pt.: Analiza porównawcza metodyk obliczania emisji GHG dla LCA bioetano$l u$ - praca INiG - PIB na zlecenie MNiSW; nr zlecenia: 0050/TP/16, nr archiwalny: DK-4100-50/16.

\section{Literatura}

[1] Berdechowski K.: Oszacowanie i porównanie wielkości emisji ditlenku węgla podczas procesów transestryfikacji $w$ instalacjach o odmiennych technologiach. Przemysł Chemiczny 2011, nr 11, s. 2006-2009.

[2] Berdechowski K.: Wytyczne obliczania emisji GHG w cyklu życia paliwa alternatywnego wytwarzanego z odpadów komunalnych. Nafta-Gaz 2015, nr 4, s. 236-241.

[3] Berdechowski K., Duda A., Laczek T.: Emisja w procesie hydrokonwersji bioolejów jako składnik emisji gazów cieplarnianych w cyklu życia (LCA) olejów napędowych. Nafta-Gaz 2012, nr 4, s. 254-259.

[4] Faber A., Jarosz Z., Borek R., Borzęcka-Walker M., Syp A., Pudełko R.: Poziom emisji gazów cieplarnianych $\left(\mathrm{CO}_{2}, \mathrm{~N}_{2} \mathrm{O}\right.$, $\left.\mathrm{CH}_{4}\right)$ dla upraw pszenicy, pszenżyta, kukurydzy i żyta przeznaczonych do produkcji bioetanolu oraz upraw rzepaku przeznaczonych do produkcji biodiesla. Ekspertyza wykonana na zlecenie Ministerstwa Rolnictwa i Rozwoju Wsi, umowa BDGzp-2125A-1/11 z dnia 10.01.2011.

[5] Lazarevic D., Martin M.: Life cycle assessments, carbon footprints and carbon visions: Analysing environmental systems analyses of transportation biofuels in Sweden. Journal of Cleaner Production 2016, vol. 137, s. 249-257.

[6] Rogowska D.: Analiza porównawcza metodyk obliczania emisji GHG dla LCA bioetanolu. Dokumentacja INiG - PIB, Kraków 2016, nr archiwalny: DK-4100-50/16.

[7] Rogowska D.: Rozeznanie problemu emisji gazów cieplarnianych szacowanych $w$ cyklu życia bioetanolu paliwowego (etap produkcji). Dokumentacja INiG - PIB, Kraków 2010, nr archiwalny: DK-4100-84/10.

[8] Rogowska D., Beredechowski K.: Ocena wplywu sposobu alokacji emisji w procesie produkcji biopaliwa na wartość emisji gazów cieplarnianych. Nafta-Gaz 2013, nr 3, s. 226-234.

[9] Rogowska D., Cierpiałowski M., Kołodziejczyk Sz., Łaczek T., Berdechowski K.: Analiza metod obliczania wartości emisji gazów cieplarnianych $\left(\mathrm{CO}_{2}, \mathrm{~N}_{2} \mathrm{O} i \mathrm{CH}_{4}\right)$ dla poszczegól- nych upraw surowców rolnych przeznaczonych do wytwarzania biokomponentów na obszarach NUTSII. Dokumentacja INiG - PIB, Kraków 2015, nr archiwalny: DK-4100-199/15.

[10] Rogowska D., Lubowicz J.: Analiza możliwości obniżenia emisji gazów cieplarnianych $w$ cyklu życia bioetanolu paliwowego. Nafta-Gaz 2012, nr 12, s. 1044-1049.

[11] Stępień A.: Produkcja, surowce, emisje - praktyczne implikacje nowelizacji krajowego prawodawstwa w obszarze wytwórczym biokomponentów. VII Konferencja Naukowo-Techniczna FUELS' ZOOM „Zrównoważony rozwój a jakość paliw”, Kraków 16-17.11.2016.

[12] The BioGrace GHG calculation tool: a recognised voluntary scheme; http://www.biograce.net/content/ghgcalculationtools/ recognisedtool/ (dostęp: wrzesień 2015).

[13] Tonini D., Hamelin L., Alvarado-Morales M., Fruergaard Astrup T.: GHG emission factors for bioelectricity, biomethane, and bioethanol quantified for 24 biomass substrates with consequential life-cycle assessment. Bioresource Technology 2016, vol. 208, s. 123-133.

\section{Akty prawne i normatywne}

[14] Dyrektywa Parlamentu Europejskiego i Rady 2009/28/WE $z$ dnia 23 kwietnia 2009 r. w sprawie promowania stosowania energii ze źródeł odnawialnych zmieniajaca $i$ w następstwie uchylajaca dyrektywy 2001/77/WE oraz 2003/30/WE (Dziennik Urzędowy Unii Europejskiej nr L 140/16 z 9.06.2009).

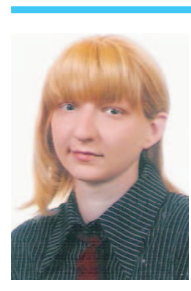

Mgr inż. Delfina ROGOWSKA

Starszy specjalista badawczo-techniczny, zastępca kierownika Zakładu Paliw i Procesów Katalitycznych. Instytut Nafty i Gazu - Państwowy Instytut Badawczy ul. Lubicz 25 A

31-503 Kraków

E-mail: delfina.rogowska@inig.pl 